there should be a national centre to foster the use of ancillary devices in teaching. The response of the Department of Education has been the creation of the national council (see Nature, 214, 225; 1967). Dr Brynmor Jones will be the chairman of the council. The intention is that the council should operate where it chooses, and there seems to be no intention that its work should be confined to higher education. Usually the council will act as a kind of grant broker, putting people with good ideas in touch with the sources from which funds are now said to be available on an increasingly generous scale. The council so far includes twenty-five ordinary members, largely from education, but the Department of Education and Science says that further representatives of industry are to be added to the list.

\section{Technology for Puerto Rico}

A CHaLlenging view of how technology may be able to transform the condition of Puerto Rico has been produced by a committee of the US National Research Council of the National Academy of Sciences and the National Academy of Engineering under Dr John C. Warner of the Carnegie Institute of Technology. The study which the committee has undertaken was commissioned by the governor of Puerto Rico. The objective was to find some means by which the living standards of the people of Puerto Rico could be made more nearly comparable with those on the mainland. This implies a more than three-fold increase of the per capita GNP (at present $\$ 930$ a year) between now and 1980. The committee has concluded that the only way of meeting these conditions is that Puerto Rico should energetically embark on a "strategy of increased productivity".

Although the committee makes no bones about the seriousness of the problems which have to be tackled in Puerto Rico, its report derives an undertone of optimism from the way in which the economy has been moving in the right direction in recent years. Thus the rate of growth of GNP per capita was $5 \cdot 1$ per cent a year throughout the fifties and early sixties, and was accelerating during that period. In spite of the rapid increase of population on the islands, Puerto Rico did better than the United States as a whole (with an average annual increase of GNP of 3.5 per cent) and much better than comparatively depressed states on the mainland such as Mississippi $(2.9$ per cent a year in the same period, but accelerating in the sixties). The growth of manufacturing industry in Puerto Rico is largely responsible for this transformation. Since 1948, the proportion of the net income of the islands earned in this way has increased from 14.9 per cent to 23.4 per cent. During the same period, net income derived from agriculture has been stagnant as a total, and has declined from $24 \cdot 6$ per cent to $8 \cdot 4$ per cent as a proportion. The report warns, however, that the industries so far established in Puerto Rico, largely as a result of economic incentives under the programmes of the Economic Development Administration, are mainly concerned with the manufacture of food, tobacco, textiles and clothes. For one thing, this implies too narrow a foundation for the indefinite future. For another, the committee points out that the industries concerned are labour intensive, which means that the economic value added by each worker's effort is comparatively smaller than it might be. This, the committee of the National Research Council believes, can only be avoided by the provision of a better system of education.

More education is not enough, however. One striking passage in the committee's argument is that Puerto Rico cannot hope for economic parity with the mainland by continuing development along directions now apparent. Although the committee urges that efforts should be made to improve productivity by investment in plant and machinery, by better rationalization of manufacturing operations, and by a better education for the labour force, it considers that these devices are "technologically limited". For this reason, the argument runs, Puerto Rico should set out deliberately to foster technological change, chiefly by trying to create in Puerto Rico (or to import from the mainland) research and development likely to lead to the emergence of new industries.

\section{Brain Drain Bibliography}

THE unit on research policy at the University of Lund has just published a bibliography of 415 items culled from the literature of $\mathbf{4 0}$ countries and concerned with problems of the migration of scientists and technologists. The document, Brain Drain and Brain Gain, is intended "as a source of information for those who are motivated to study the various aspects of the migration of scientists by the needs of policy or by the delight of scientific curiosity". Although the bibliography may seem to serious scholars to be incomplete in several ways, it does throw light on the reading habits of those who have compiled it. Thus the compilers seem to have kept a close watch on publications in English, such as the New York Times and even Nature. By contrast, two of the three references to Le Monde date back to 1964 . (The other is undated.)

\section{Computer Catalogue}

A contract for the development of library catalogues in machine readable form has been placed with the University of Newcastle upon Tyne by the Office for Scientific and Technical Information. The office is proposing to contribute $£ 12,500$ towards the cost of a two year project being undertaken by Professor E. S. Page, professor of computing and data processing at the university, and Mr M. B. Line, the deputy librarian. Professor Page has in the past few years been responsible for the work necessary to make the MEDLARS retrieval system of the US National Library of Medicine accessible to research workers in the United Kingdom.

The new project is intended to be of general value to university librarians, and possibly to others as well. One task will be to explore the problems of converting an existing catalogue to computer language. The entire catalogue of the university library at Newcastle will be punched on to paper tape, and an attempt will be made to decide whether this can be recast in some more suitable form, possibly by the use of automatic computer programmes for editing individual catalogue entries. The project is also designed to discover what kinds of catalogues are likely to be most directly of value to readers. As part of the work to be undertaken, several variants of conventional catalogues will be produced by the computer from the main catalogue. 